\title{
INCREASED OASIS INCIDENCE - INDICATOR OF THE QUALITY OF OBSTETRIC CARE?
}

\author{
Vesna Košec ${ }^{1}$, Ivka Djaković ${ }^{1},{\text { Marijo Čukelj }{ }^{1}, \text { Emina Ejubović }}^{2,3}$, \\ Blaženka Sumpor ${ }^{1}$ and Željko Djaković ${ }^{4}$
}

\begin{abstract}
${ }^{1}$ Department of Gynecology and Obstetrics, Sestre milosrdnice University Hospital Centre, Zagreb, Croatia; ${ }^{2}$ Department of Gynecology and Obstetrics, Zenica Cantonal Hospital, Zenica, Bosnia and Herzegovina; ${ }^{3}$ Sarajevo Medical School, Sarajevo School of Science and Technology, Sarajevo, Bosnia and Herzegovina; ${ }^{4}$ Jordanovac Department of Thoracic Surgery, Zagreb University Hospital Centre, Zagreb, Croatia
\end{abstract}

SUMMARY - In the era of new molecular, epigenetic and proteomic discoveries, birth canal injuries seem like outdated discussion. A vast increase in the incidence of obstetric anal sphincter injuries (OASIS) has been recorded in the last two decades despite advantages in modern medicine and new obstetric methods. This increase might be attributed to the new classification of perineal injury but also to the new imaging methods, including endoanal sonography, which earlier identifies injuries that previously were considered to be occult and actually underwent unrecognized, and which should have been recognized immediately postpartum. OASIS are third and fourth degree perineal injuries that occur during delivery. The reported incidence of OASIS varies from $0.1 \%$ to $10.9 \%$. It is well known that third and fourth degree perineal injuries occur more often in primiparae, and in cases of macrosomic newborn, dorsoposterior position of fetal head and shoulder dystocia. The protective role of episiotomy is controversial. Birth canal injury during delivery can happen to any parturient woman. It is important for obstetricians to have this in mind at every delivery. Repercussions of OASIS are serious and can persist for life. They include emotional, psychological, social, physical and sexual disturbances. Therefore, it is very important to recognize the risk factors, diagnose the injury on time and treat it properly by a multidisciplinary team. Accordingly, it can be concluded that the increased incidence of OASIS is a result of better recognition of the risk factors, reduced rates of unrecognized sphincter injuries, adoption of the new classification and better postpartum imagining methods for detection of occult injuries. effects

Key words: Birth injuries; Perineum - injuries; Anal canal - injuries; Delivery, obstetric - adverse

\section{Introduction}

In the era of new molecular, epigenetic and proteomic discoveries, birth canal injuries seem like outdated discussion. This very topic might seem monotonous to ambitious obstetrician. Hence the fact of significantly differing reports on the incidence of third

Correspondence to: Ivka Djakovic, $M D, P h D$, Department of Gynecology and Obstetrics, Sestre milosrdnice University Hospital Centre, Vinogradska c. 29, HR-10000 Zagreb, Croatia

E-mail: ivkadj@yahoo.com

Received September 7, 2016, accepted September 15, 2018 and fourth degree perineal injuries should actuate incredible curiosity considering that young women in their twenties suffering such injury may have extensive consequences in their future social, psychological and sexual aspects of life, but can also have major impact on planning and accepting next pregnancy. It is the reason why the approach to patients should be individualized and every perineal injury should be carefully diagnosed in order not to miss third and fourth perineal rupture and leave it unrecognized. If the injury is recognized on time, all the previously mentioned negative effects can easily be avoided. 
Obstetric anal sphincter injuries (OASIS) are third and fourth degree perineal injuries occurring during delivery. Third degree rupture of the perineum is divided in three grades: $3 \mathrm{a}$, up to $50 \%$ of external anal sphincter involved; $3 \mathrm{~b}$, over $50 \%$ of external anal sphincter involved; and 3c, injury of external and internal anal sphincter. Fourth degree represents injury of anal sphincter and rectum ${ }^{1-3}$.

Rectal injury with intact anal sphincter is a separate entity and does not qualify for fourth degree perineal rupture according to the new Royal College of Obstetricians and Gynaecologists (RCOG) guidelines ${ }^{3}$.

There is a large increase of OASIS incidence recorded in the last two decades despite advantages in modern medicine and new obstetric methods ${ }^{4-6}$. The number of OASIS cases has tripled in England from 2000 to $2012^{3}$. Thus, it is a major concern and reason to question the new obstetric standards ${ }^{6-13}$.

This vast increase might be attributed not only to the new classification of perineal injury but also to the new imaging methods including endoanal sonography, which earlier identifies injuries that previously were considered to be occult and actually underwent unrecognized, and which should have been recognized immediately postpartum. The reported incidence of OASIS varies from $0.1 \%$ to $10.9 \% \%^{4,9,14-17}$. There is the need to recognize the risk factors and prevent OASIS whenever possible ${ }^{8,17,18}$.

Differences in OASIS incidence have been observed between countries that are geographically, culturally and socioeconomically different but also in similar countries (e.g., Nordic countries) ${ }^{4,6}$. The rates of OASIS range from $0.1 \%$ in Romania, $0.6 \%$ in Finland to $4.2 \%$ in Sweden and $4.9 \%$ in Iceland ${ }^{4,6}$.

Changes in eating habits in the past decades, which have led to maternal obesity, also contribute to increase in newborn weight. It is a relatively new phenomenon, so that birth canal could not follow these changes. Disproportion of the newborn weight and birth canal is the reason for the increased number of delivery-related injuries of birth canal ${ }^{19}$.

Elective cesarean section for estimated newborn weight over $4500 \mathrm{~g}$ in diabetic mothers and $5000 \mathrm{~g}$ in non-diabetic mothers decreases newborn injuries, induced and instrumental delivery rates, shoulder dystocia, prolonged second stage of labor, as well as the rate of birth canal injuries ${ }^{2,3,19}$.
Selection of pregnant women meeting these criteria is crucial in obstetric care in order to avoid unnecessary perineal tears because repercussions of OASIS persist for life and include emotional, psychological, social, physical and sexual disturbances. Therefore, it is very important to recognize the risk factors on time, minimize them as much as possible, diagnose injury on time and treat it properly by a multidisciplinary team ${ }^{1-3,20-22}$.

\section{Risk Factors}

The risk factors for OASIS are birth weight over $4000 \mathrm{~g}$, primiparity, induced labor, prolonged second stage of labor, maternal age, shoulder dystocia, medial episiotomy, vacuum extraction (VE), occipitoposterior position, newborn's head circumference and early morning delivery ${ }^{1-3,14}$. All authors agree that primiparity is certainly a risk factor for third and fourth degree perineal injuries ${ }^{1-4,7,9,11,14,16-18,20,21,25,31}$.

Late motherhood is common nowadays and the number of parturient women over 40 years of age is significant ${ }^{23,24}$. The quality of collagen reduces with age and injury is more likely to occur. However, maternal age as a risk factor is controversial because some authors consider age over 25 as a risk factor ${ }^{2,3,14,25}$. There are no new reports on maternal age as a risk factor. Even the revised RCOG guidelines from 2015 do not take maternal age in consideration ${ }^{3}$. Older women also have comorbidities. Their pregnancies are more often the result of assisted reproduction methods and their pregnancies more often are terminated by cesarean section $^{26}$. In our experience, maternal age does not represent a risk factor for OASIS $^{22}$.

The protective role of episiotomy is controversial. It is well known that medial episiotomy increases the incidence of OASIS ${ }^{3,14}$. Reports on mediolateral episiotomy are inconclusive. Some authors report decrease in the incidence of third and fourth degree perineal injuries, whereas others found no connection between mediolateral episiotomy and OASIS $2,3,6,14,17,25,27-29$. The rate of episiotomy varies from $3.7 \%$ in Denmark to $75.0 \%$ in Cyprus ${ }^{6}$. This might be the reason for inconclusive results concerning connection of episiotomy and third and fourth degree perineal injuries. Nevertheless, episiotomy has its place in instrumental delivery and it should not be avoided if indicated. The most important single risk factor for OASIS is instrumental 
delivery with forceps without episiotomy, followed by VE without episiotomy ${ }^{3}$. The risk for OASIS in cases of instrumental delivery decreases with episiotomy $y^{3,30}$. A large retrospective study including over 40000 women found that episiotomy had no effect on third and fourth degree perineal injuries in primiparae and even increased the risk of injury in multiparae ${ }^{31}$. A recent study found no connection between vacuum extraction and episiotomy; the more so, the authors found no connection between VE and $\mathrm{OASIS}^{30}$. However, consensus has been achieved for macrosomic newborns, dorsoposterior position and shoulder dystocia to increase the risk of third and fourth degree perineal injuries ${ }^{1-3,14,16,21,22,25,32}$.

Most obstetricians find labor induction and use of oxytocin as risk factors for OASIS, but some studies conclude that labor augmentation does not increase the incidence of instrumental delivery ${ }^{33,34}$.

Prolonged second stage of labor progressively increases the risk of OASIS ${ }^{3,35-37}$. Considering the strict recommendations for duration of second stage of labor, it is questionable whether second stage of labor should last longer than two hours in primiparae and one hour in multiparae, except for cases of epidural administration when second stage is prolonged for one more hour ${ }^{38,39}$. There are even several studies showing epidural analgesia to be associated with a reduced risk of OASIS ${ }^{37}$.

Ethnicity is a very important risk factor for OASIS. Asian women have the highest risk of third and fourth degree perineal injuries ${ }^{3}$. Another interesting study has shown that African women had a nearly fourfold risk of anal sphincter tear during VE compared with Swedish-born women ${ }^{30}$. Meister et al. included nonblack race among significant predictors of OASIS ${ }^{36}$.

\section{Discussion}

Birth canal injury during delivery can happen to any parturient woman ${ }^{3,22}$. It is important for obstetricians to bear it in mind at every delivery. Apparently developed world and better standard does not protect women from OASIS. An interesting study from 2008, carried out by Prager et al. found the risk of OASIS to be 23 times higher in women delivering in the Swedish setting ${ }^{37}$. Great differences among countries have already been noted above $e^{4,6}$.
Some authors consider stress delivery in morning hours to be a risk factor ${ }^{14}$. Delivery position is crucial. Good visualization and timely episiotomy decrease the risk of OASIS. In order to reduce the risk of OASIS, manual perineal protection should be performed with the left hand slowing down the delivery of the head while protecting the perineum with the right hand. Communication with the mother is very important. She should not push when the head is in the crowning phase. Correct angle episiotomy is performed in risk groups ${ }^{3,16}$.

It is very important to recognize the injury of birth canal. There are reports on many unrecognized perineal injuries, especially third degree perineal tear ${ }^{3,8,40,41}$. Long-lasting repercussions can occur even in cases of first and second degree injuries. Therefore, every woman must be thoroughly examined including digitorectal examination in order to exclude rare buttonhole tear injury ${ }^{4}$.

The importance of digitorectal examination after lateral episiotomy repair is great because anorectal mucosa may be injured by inadequately placed suture. If this situation is unrecognized and the suture is not removed, formation of a rectovaginal fistula is probable ${ }^{3}$.

Early complications of OASIS are wound disruption and purulent discharge. Late complications are anal and fecal incontinency and fistulas ${ }^{1,15,18,42-44}$.

Anal incontinence after OASIS was associated significantly only with maternal age and duration of second stage of labor. The degree of sphincter damage at delivery (IIIa, b, c, IV) was not associated with the risk of anal incontinence at 2 months postpartum ${ }^{45}$.

In order to avoid these complications, the physician repairing the injury should be experienced, and if the injury is large then the surgeon should be included for long-lasting results are better if the injury repair is performed by colorectal surgeon ${ }^{46-48}$.

Problems can arise when colorectal surgeon is not available at the time of injury. Repair technique is also a very important factor that can influence the quality of OASIS care. End-to-end technique with interrupted sutures or figure of eight sutures were used in the past century but showed some disadvantages. Overlap should be used in every case of complete external anal sphincter $3 \mathrm{~b}$ injury, as this technique gives better endoanal sonography results. Infectious morbidity associated with repair of third and fourth degree perineal injuries can be accomplished by prophylactic antibiot- 
ics; if maternal body mass index is $>35$, the dose can be doubled ${ }^{11}$.

If there is any doubt about the degree of injury, it is always better to classify it higher ${ }^{3}$. Unrecognized and misclassified OASIS might be the reason for the reported incidence that is lower than in reality.

There are attempts to construct a device that would prevent OASIS but results are not promising. Lavesson's special perineal device and Epi-No birth trainer failed to reduce the rates of episiotomy and perineal tears ${ }^{49-51}$. Special perineum designed scissors are being developed $^{52}$. In order to have the best effect in the prevention of perineal injuries, various types of gels are being invented and introduced to medical practice for their suitability and safety in use ${ }^{53}$.

\section{Conclusion}

It is a consensual opinion that parity, macrosomic newborns, dorsoposterior position and shoulder dystocia increase the risk of third and fourth degree perineal injury. So, the question is: does the increase in the incidence of OASIS reflect poor obstetric care? For the reasons mentioned above, it need not be so. The increased number of OASIS cases can also imply better obstetric care because detection of the injuries is nowadays better and therefore appropriate treatment is applied, intrapartum or postpartum. New methods of better perineal protection are being developed and introduced in daily practice in order to minimize the rates of OASIS.

\section{References}

1. Frohlich J, Kettle C. Perineal care. BMJ Clin Evid. 2015;2015. pii1401.

2. Royal College of Obstetricians and Gynaecologists. The management of third- and fourth-degree perineal tears. (Green-top Guideline No.29). March 2007.

3. Royal College of Obstetricians and Gynaecologists. The management of third- and fourth-degree perineal tears. (Green-top Guideline No. 29). June 2015.

4. Laine K, Gissler M, Pirhonen J. Changing incidence of anal sphincter tears in four Nordic countries through the last decades. Eur J Obstet Gynecol Reprod Biol. 2009;146(1):71-5. http://dx.doi.org/ 10.1016/j.ejogrb.2009.04.033.

5. Lindgren HE, Brink A, Klinberg-Allvin M. Fear causes tearsperineal injuries in home birth settings. A Swedish interview study. BMC Pregnancy Childbirth. 2011;11:6. http://dx.doi. org/ 10.1186/1471-2393-11-6.
6. Blondel B, Alexander S, Bjarnadóttir RI, Gissler M, LanghoffRoos J, Novak-Antolič Ž, et al. Variations in rates of severe perineal tears and episiotomies in 20 European countries: a study based on routine national data in Euro-Peristat Project. Acta Obstet Gynecol Scand. 2016;95(7):746-54. http://dx.doi. org/ 10.1111/aogs.12894.

7. Baghurst PA. The case for retaining severe perineal tears as an indicator of the quality of obstetric care. Aust N Z J Obstet Gynaecol. 2013;53(1):3-8. http://dx.doi.org/10.1111/ajo.12014.

8. Baghurst PA, Antoniou G. Risk models for benchmarking severe perineal tears during vaginal childbirth: a cross-sectional study of public hospitals in South Australia, 2002-08. Paediatr Perinat Epidemiol. 2012;26(5):430-7. http://dx.doi. org/10.1111/j.1365-3016.2012.01300.x.

9. Rizvi RM, Chaudhury N. Practices regarding diagnosis and management of third and fourth degree perineal tears. J Pak Med Assoc. 2008;58(5):244-7.

10. Panigrahy R, Welsh J, MacKenzie F, Owen P; Perinatal Effectiveness Committee in Glasgow (PEC). A complete audit cycle of management of third/fourth degree perineal tears. J Obstet Gynaecol. 2008;28(3):305-9. http://dx.doi.org/10.1080/01443610802054980.

11. van Schalkwyk J, Van Eyk N; Society of Obstetricians and Gynaecologists of Canada Infectious Diseases Committee. Antibiotic prophylaxis in obstetric procedures. J Obstet Gynaecol Can. 2010;32(9):878-92. http://dx.doi.org/10.1016/ S1701-2163(16)34662-X.

12. Tolcher MC, El-Nashar SA, Famuyide AO. Evaluation of third-degree and fourth-degree laceration rates as quality indicators. Obstet Gynecol. 2015;126(1):215-6. http://dx.doi.org/ 10.1097/AOG.0000000000000940.

13. Friedman AM, Ananth CV, Prendergast E, D‘Alton ME, Wright JD. Evaluation of third-degree and fourth-degree laceration rates as quality indicators. Obstet Gynecol. 2015; 125(4):927-37. http://dx.doi.org/10.1097/AOG.0000000000 000720 .

14. Jander C, Lyrenas S. Third and fourth degree perineal tears. Predictor factors in a referral hospital. Acta Obstet Gynecol Scand. 2001;80(3):229-34.

15. Buppasiri P, Lumbiganon P, Thinkhamrop J, Thinkhamrop B. Antibiotic prophylaxis for third- and fourth-degree perineal tear during vaginal birth. Cochrane Database Syst Rev. 2014; 10:CD005125. http://dx.doi.org/10.1002/14651858.CD005125.pub4.

16. Samuelsson E, Ladfors L, Wennerholm UB, Gareberg B, Nyberg K, Hagberg H. Anal sphincter tears: prospective study of obstetric risk factors. BJOG. 2000;107(7):926-31.

17. Hsieh WC, Liang CC, Wu D, Chang SD, Chueh HY, Chao AS. Prevalence and contributing factors of severe perineal damage following episiotomy-assisted vaginal delivery. Taiwan J Obstet Gynecol. 2014;53(4):481-5. http://dx.doi.org/10.1016/j.tjog.2013.07.002. 
18. LaCross A, Groff M, Smaldone A. Obstetric anal sphincter injury and anal incontinence following vaginal birth: a systemic review and meta-analysis. J Midwifery Womens Health. 2015;60(1):37-47. http://dx.doi.org/10.1111/jmwh.12283.

19. Vraneš HS, Djaković I. Length and weight of newborns in Croatia from 1985 to 2009. Wien Klin Wochenschr. 2015;127 (17-18):685-90. http://dx.doi.org/10.1007/s00508-014-0686-2.

20. Cornelisse S, Arendsen LP, van Kuijk SM, Kluivers KB, van Dillen J, Weemhoff M. Obstetric anal sphincter injury: a follow-up questionnaire study on longer-term outcomes. Int Urogynecol J. 2016;27(10):1591-6. http://dx.doi.org/ 10.1007/ s00192-016-3017-5.

21. Djaković I, Sabolović Rudman S, Jukić M, Košec V.Trogodišnje iskustvo KBCSM sa rupturama međice trećeg i četvrtog stupnja. Gyneacol Perinatol. 2015;24(Suppl.2):118-9. (in Croatian)

22. Kwon HY, Park HS. Episiotomy and the risk of severe perineal injuries among Korean women. J Matern Fetal Neonatal Med. 2017;30(14):1745-1749. http://dx.doi.org/ 10.1080/14767058.2016.1224833.

23. Lemoine ME, Ravitsky V. Sleepwalking into infertility: the need for a public health approach toward advanced maternal age. Am J Bioeth. 2015;15(11):37-48. http://dx.doi.org/ 10.1080/15265161.2015.1088973.

24. Castro-Vázquez G. Late-in-life childbearing (kōrei shussan) in contemporary Japan. Cult Health Sex. 2015;17(10):1221-36. http://dx.doi.org/10.1080/13691058.2015.1048528.

25. Gurol-Urganci I, Cromwell DA, Edozien LC, Mamhood TA, Adams EJ, Richmond DH, Templeton A, van der Meulen JH. Third- and fourth-degree perineal tears among primiparous women in England between 2000 and 2012. Time trends and risk factors. BJOG. 2013;120(12):1516-25. http://dx.doi. org/10.1111/1471-0528.12363.

26. Ben-David A, Glasser S, Schiff E, Zahav AS, Boyko V, LernerGeva L. Pregnancy and birth outcomes among primiparae at very advanced maternal age: at what price? Matern Child Health J. 2016;20(4):833-42. http://dx.doi.org/10.1007/ s10995-015-1914-8.

27. Jango H, Langhoff-Roos J, Rosthoj S, Sakse A. Modifiable risk factors of obstetric anal sphincter injury in primiparous women: a population-based cohort study. Am J Obstet Gynecol. 2014;210(1):59.e1-6. http://dx.doi.org/10.1016/j.ajog.2013.08.043.

28. Amorim MM, Franca-Neto AH, Leal NV, Melo FO, Maia SB, Alves JN. Is it possible to never perform episiotomy during vaginal delivery? Obstet Gynecol. 2014;123 Suppl 1:38S.

29. Valsky DV, Cohen SM, Lipschuetz M, Hochner-Celnikier D, Daum H, Yagel I, Yagel S. Third- or fourth-degree intrapartum anal sphincter tears are associated with levator ani avulsion in primiparas. J Ultrasound Med. 2016;35(4):709-715. http:// dx.doi.org/10.7863/ultra.15.04032.

30. Ryman P, Ahlberg M, Ekéus C. Risk factors for anal sphincter tears in vacuum-assisted delivery. Sex ReprodHealthc. 2015;6(3):151-6.

http://dx.doi.org/10.1016/j.srhc.2015.02.005.
31. Shmueli A, Gabbay Benziv R, Hiersch L, Ashwal E, Aviram R, Yogev Y, Aviram A. Episiotomy - risk factors and outcomes. J Matern Fetal Neonatal Med. 2017;30(3):251-256. http://dx. doi.org/ 10.3109/14767058.2016.1169527.

32. McPherson KC, Beggs AD, Sultan AH, Thakar R. Can the risk of obstetric anal sphincter injuries (OASIs) be predicted using a risk-scoring system? BMC Res Notes. 2014;7:471. http:// dx.doi.org/10.1186/1756-0500-7-471.

33. Stock SJ, Ferguson E, Duffy A, Ford I, Chalmers J, Norman JE. Outcomes of elective induction of labour compared with expectant management: population based study. BMJ. 2012 May 10;344:e2838. http://dx.doi.org/10.1136/bmj.e2838.

34. Eskandar O, Shet D. Risk factors for $3^{\text {rd }}$ and $4^{\text {th }}$ degree perineal tear. J Obstet Gynaecol. 2009 Feb;29(2):119-22. http://dx.doi. org/10.1080/01443610802665090.

35. Garmi G, Peretz H, Braverman M, Berkovich I, Molnar R, Sa$\lim$ R. Risk factors for obstetric anal sphincter injury: to prolong or to vacuum? Midwifery. 2016;34:178-82. http://dx.doi. org/10.1016/j.midw.2015.11.012.

36. Meister MR, Cahill AG, Conner SN, Woolfolk CL, Lowder JL. Predicting obstetric anal sphincter injuries in a modern obstetric population. Am J Obstet Gynecol. 2016;215(3):310. e1-7. http://dx.doi.org/ 10.1016/j.ajog.2016.02.041.

37. Prager M, Andersson KL, Stephansson O, Marchionni M, Marions L. The incidence of obstetric anal sphincter rupture in primiparous women: a comparison between two European delivery settings. Acta Obstet Gynecol Scand. 2008;87(2): 209-15. http://dx.doi.org/10.1080/00016340701832661.

38. Bilić N, Djaković I, Kličan-Jajić K, Sabolović Rudman S, Ivanec $\check{Z}$. Epidural analgesia in labor - controversies. Acta Clin Croat. 2015;54(3):330-6.

39. ACOG Committee Opinion 295: Pain relief during labor. Obstet Gynecol. 2004;104(1):213.

40. Villot A, Deffieux X, Demoulin G, Rivain AL, Trichot C, Thubert T. Management of third and fourth degree perineal tears: a systematic review. J Gynecol Obstet Biol Reprod (Paris). 2015;44(9):802-11.

http://dx.doi.org/10.1016/j.jgyn.2015.06.005.

41. Martínez Hernández Magro P, Villanueva Sáenz E, Jaime Zavala M, Sandoval Munro RD, Rocha Ramírez JL. Endoanal sonography in assessment of fecal incontinence following obstetric trauma. Ultrasound Obstet Gynecol. 2003;22(6); 616-21. http://dx.doi.org/ 10.1002/uog.919

42. Fitzpatrick M, O'Herlihy C. Short-term and long-term effects of obstetric and sphincter injury and their management. Curr Opin Obstet Gyneacol. 2005;17:605-10.

43. Guise JM, Morris C, Osterweil P, Li H, Rosenberg D, Greenlick $\mathrm{M}$. Incidence of fecal incontinence after child birth. Obstet Gynecol. 2007;109:281-8. http://dx.doi.org/10.1097/01. AOG.0000254164.67182.78

44. Halle TK, Salvesen KÅ, Volløyhaug I. Obstetric anal sphincter injury and incontinence $15-23$ years after vaginal delivery. Acta 
Obstet Gynecol Scand. 2016;95(8):941-7. http://dx.doi. org/10.1111/aogs.12898.

45. Ménard S, Poupon C, Bourguignon J, Théau A, Goffinet F, Le Ray C. Predictive factors of 2-month postpartum anal incontinence among patients with an obstetrical anal sphincter injury. J Gynecol Obstet Biol Reprod (Paris). 2016;45(8):900-907. http://dx.doi.org/10.1016/j.jgyn.2015.12.008.

46. McNikol FJ, Bruce CA, Chaudhri S, Francombe J, Kozman E, Taylor BA, Tighe MJ. Management of obstetric anal sphincter injuries - a role for the colorectal surgeon. Colorectal Dis. 2010;12(9);927-30. http://dx.doi.org/10.1111/j.1463-1318.2009.01897.x.

47. Kirss J, Pinta T, Böckelman C, Victorzon M. Factors predicting a failed primary repair of obstetric anal sphincter injury. Acta Obstet Gynecol Scand. 2016;95(9):1063-9. http://dx.doi. org/10.1111/aogs.12909.

48. Djaković I, Ejubović E, Bolanča I, Markuš-Sandrić M, Bečić D, Djaković Ž, Košec V. Third and fourth degree perineal tear in four-year period at Sestre milosrdnice University Hospital Center, Zagreb, Croatia. Open Access Maced J Med Sci. 2018; 6(6):1067-1071. http://dx.doi.org/10.3889/oamjms.2018.253.

49. Lavesson T, Griph ID, Skarvad A, Karlsson AS, Nilsson HB, Steinvall M, Haadem K. A perineal protection device designed to protect the perineum during labor: a multicenter random- ized controlled trial. Eur J Obstet Gynecol Reprod Biol. 2014;181:10-4.

http://dx.doi.org/10.1016/j.ejogrb.2014.07.006.

50. Brito LG, Ferreira CH, Duarte G, Nogueira AA, Marcolin AC. Antepartum use of Epi-No birth trainer for preventing perineal trauma: systematic review. Int Urogynecol J. 2015;26(10): 1429-36. http://dx.doi.org/10.1007/s00192-015-2687-8.

51. Kamisan Atan I, Shek KL, Langer S, Guzman Rojas R, Caudwell-Hall J, Daly JO, Dietz HP. Does the Epi-No $\left({ }^{\circledR}\right)$ birth trainer prevent vaginal birth-related pelvic floor trauma? A multicentre prospective randomised controlled trial. BJOG. 2016;123(6):995-1003. http://dx.doi.org/10.1111/1471-0528.13924.

52. van Roon Y, Kirwin C, Rahman N, Vinayakarao L, Melson L, Kester N, Pathak S, Pradhan A. Comparison of obstetric anal sphincter injuries in nulliparous women before and after introduction of the EPISCISSORS-60 $\left.{ }^{\circledR}\right)$ at two hospitals in the United Kingdom. Int J Womens Health. 2015;7:949-55. http://dx.doi.org/10.2147/IJWH.S94680.

53. Ashwal E, Aviram A, Wertheimer A, Krispin E, Kaplan B, Hiersch L. The impact of obstetric gel on the second stage of labor and perineal integrity: a randomized controlled trial. J Matern Fetal Neonatal Med. 2016;29(18):3024-9. http://dx. doi.org/10.3109/14767058.2015.1114079.

Sažetak

\title{
JE LI POVEĆANJE INCIDENCIJE OASIS-a POKAZATELJ LOŠIJE OPSTETRIČKE SKRBI?
}

\author{
V. Košec, I. Djaković, M. Čukelj, E. Ejubović, B. Sumpor i Ž. Djaković
}

U eri novih molekularnih, epigenetičkih i proteomskih otkrića porođajne ozljede izgledaju kao zastarjela tema za raspravu. U posljednja dva desetljeća zabilježen je porast ozljeda analnog sfinktera tijekom porođaja unatoč napretcima moderne medicine i novim porođajnim metodama. Ovo povećanje moglo bi se pripisati novoj klasifikaciji perinealnih ozljeda, ali i novim slikovnim metodama uključujući endoanalnu sonografiju koja kvalificira ozljede za koje se smatra da su prije bile okultne, zapravo neprepoznate, a trebale su biti prepoznate odmah nakon porođaja. U opstetričke ozljede analnog sfinktera se ubrajaju treći i četvrti stupanj razdora međice tijekom porođaja. Učestalost ovih ozljeda varira od $0,1 \%$ do $10,9 \%$. Poznato je da je razdor međice trećeg i četvrtog stupnja češći u prvorotkinja te u slučajevima makrosomnog novorođenčeta, dorsoposteriornom položaju fetalne glavice i kod distocije ramena. Zaštitna uloga epiziotomije je proturječna. Ozljeda porođajnog kanala se može dogoditi kod bilo koje žene u porođaju, što porodničar uvijek mora imati na umu. Razdori međice trećeg i četvrtog stupnja mogu imati ozbiljne dalekosežne posljedice koje uključuju emocionalne, psihološke, socijalne, fizičke i seksualne poremećaje. Stoga je vrlo važno prepoznati čimbenike rizika, dijagnosticirati ozljedu na vrijeme i zbrinuti ju na odgovarajući način uz multidisciplinarni pristup. Uza sve navedeno može se zaključiti da je povećana učestalost OASIS-a rezultat boljeg prepoznavanja čimbenika rizika, smanjene stope neprepoznate ozljede sfinktera, uvođenja nove klasifikacije i boljih slikovnih metoda koje postpartalno mogu otkriti okultne ozljede.

Ključne riječi: Porođajne ozljede; Perineum - ozljede; Analni kanal-ozljede; Porođaj-štetna djelovanja 